The Journal of Animal \& Plant Sciences, 30(5): 2020, Page: 1123-1128

ISSN (print): 1018-7081; ISSN (online): 2309-8694

\title{
EFFECTS OF COATING WITH CHITOSAN FILM AND STORING AT DIFFERENT PERIODS OF BROOD BROILER EGGS ON HATCHING PERFORMANCE
}

\author{
Abdurrahman Koseman ${ }^{1}$, Fatih Akdemir ${ }^{2}$ and İbrahim Şeker ${ }^{3 *}$ \\ ${ }^{1}$ Department of Crop and Animal Production, Akcadag Vocational School, Turgut Ozal University, Malatya, Turkey. \\ ${ }^{2}$ Department of Zootechny, Faculty of Agriculture, Malatya Turgut Ozal University, Malatya, Turkey. \\ ${ }^{3}$ Department of Veterinary Zootechny, Faculty of Veterinary Medicine, Firat University, Elazig, Turkey. \\ *Corresponding author's email: iseker@firat.edu.tr
}

\begin{abstract}
The aim of this study was to investigate the effects of coating with chitosan film and storing at different times (from 7 days to 21 days) of Ross 308 brood broiler eggs on weight loss of the eggs and hatching performance. In this study, the experimental treatments consisted of three different storage periods (7, 14 and 21 days) and eggs of each of these groups were further divided in two sub groups as coating with chitosan film (group A, C and E) or not (group B, D and F). In total, six treatment groups were formed for the study. Total number of eggs used in the study was 1800 . In all groups with chitosan coated, high early embryonic mortality (over 90\%) and low mid and late embryonic mortality were observed $(2.41 \%-6.89 \%)(\mathrm{p}<0.05)$. The lowest hatchability was observed in groups $\mathrm{A}, \mathrm{C}$ and $\mathrm{E}$, which coated with chitosan film $(0.67 \%, 3.00 \%$ and $0.33 \%$, respectively). It was further observed that coating the fertilised broiler breeder eggs with chitosan film for different storage periods significantly decreased weight losses in the eggs, both during storage and incubation. However, the expected positive effects on hatchability of incubated eggs were not actually observed. Conversely, the coating of eggs with chitosan film adversely affected the embryonic mortality and the hatching performance.
\end{abstract}

Keywords: broiler, chitosan, hatchability, storage period.

https://doi.org/10.36899/JAPS.2020.5.0128

Published online June 25, 2020

\section{INTRODUCTION}

Many methods are being studied in order to delay the expiry dates of nutrients, to improve their quality and taste, and to prevent the negative effects of the environment, including packaging with edible film (Xie et al., 2002; Suyatma et al., 2005). Among those films, food covers made up of polysaccharides, including chitine, chitosan, cellulose derivatives, alginates, algae, pectines, starch and starch derivatives are common (Kucukoner et al., 2003). The main principle in covering food with edible films is to form a layer on the surface of the food in order to protect the food from environmental effects, and to delay the spoilage of the food (Lee et al., 2003; Suyatma et al., 2005). Egg covering studies conducted with chitosan film in particular, have reported beneficial outcomes including reduced weight loss and delayed expiry date for 2-3 weeks in eggs covered with chitosan film (No et al., 2005). In another study the effects of chitosan film cover materials made up using acetic acid, lactic acid and propionic acid on shelf lifes and shell strength of commercial eggs were observed, the eggs covered with chitosan film were observed to have a stabilised albumen $\mathrm{pH}$, reduced mass transfer, delayed freshness and related delayed prolonged shelf life (Reijrink et al., 2008). Furthermore, the rates of fracture and breakage of the eggs were reduced, and the inner quality of the eggs was protected (Caner and Cansiz 2007).

For profitable breeding, the duration and conditions of storage of the eggs used in hatching companies are as important as the commercial eggs used as food for human, (Aksoy 1991). However, the increased duration of storage, which sometimes becomes necessary leads to weight loss in the eggs, and the resistance of the egg shell to breakage decreases with the effect of high temperature (McWilliams 2001; Avan and Alisarli 2002; Berardinelli et al., 2003). As the egg loses moisture, the volume of air cell increases, the late-term embryo death rate increases, and output power of fertilized eggs reduces, the embryo development in brood decelerates and hatching is delayed (Fasenko et al., 1992; Meijerhof 1992; Walsh et al., 1995; McWilliams 2001; Senkoylu 2001; Altan et al., 2002). Additionally, the internal quality of the eggs decreases and the $\mathrm{pH}$ increases (Walsh et al., 1995; Brake et al., 1997).

Despite all these disadvantages, the storage time of the eggs may exceed seven days in some commercial chick production farms. Generally, storage of hatching eggs for more than seven days is not recommended because, no matter how proper the conditions of storage are the hatchability decreases after one week (Ipek et al., 1999).

Currently, different applications and various scientific research have been conducted in order to 
prevent the disadvantages occurring during long-term storage of commercial and hatching eggs (Otles and Hisil 1990; Caner 2005; Durmus et al., 2009; Dorosti et al., 2019); however, we could not access any study investigating the effects of chitosan film cover on weight losses during incubation and hatchability of incubated eggs in different storage conditions.

Therefore, this study was conducted to investigate the effects of coating with chitosan film and storing for one week or longer of Ross 308 brood broiler eggs on weight loss of the eggs and some hatchability characterisitcs, and to determine whether it may be used to eliminate or reduce the storage-related negative outcomes or not.

\section{MATERIALS AND METHODS}

The present study was conducted at the Poultry Research Unit of the Department of Plant and Animal Production, Inonu University Akcadag High School. The ethics committee approval was obtained from Animal Research at Inonu University, Malatya, Turkey (approval no: 2017/A-15). A total of 1800 fertilized Ross 308 broiler breeder eggs, which were aged between 36-40 weeks and had a mean weight of $59.9 \pm 0.1 \mathrm{~g}$, were obtained from a commercial company in Malatya, Turkey.

High molecular weight chitosan (310000375000 Da, Poliglusam; Deacetylchitin; Poly-(D) glucosamine; Sigma-Aldrich: CAS 9012-76-4) was used to coating the eggs in study groups. In order to increase the solubility and efficacy of the coating material (chitosan), 1\% acetic acid (Glacial acetic acid; $\mathrm{CH}_{3} \mathrm{CO}_{2} \mathrm{H}$ ) of 60.05 molecular weight was used. Also, glycerol $(0,25 \mathrm{ml} / \mathrm{g}$ chitosan) was used as a plasticizer to avoid the fragility of the coating and improve the film layer formation.

The present study was arranged for $3 \times 2$ factorial design; three different storage periods (7, 14 and 21 days) and two administration as coating with chitosan film of the eggs or not. A total of 1800 hatching fertilized eggs were divided into six groups with 100 eggs in each and 600 eggs at every independent repeat (3 times) as follows:

Group A, C and E: 7, 14 and 21 days of storing and coated with chitosan film, Group B, D and F: 7, 14 and 21 days of storing, respectively. The experimental design of the study was presented in Table 1.

The weights of the eggs $(59.9 \pm 0.1 \mathrm{~g})$ were recorded prior to storage, at the beginning of incubation and on the $18^{\text {th }}$ day of incubation. The eggs in the study groups with no chitosan cover (B, D and $\mathrm{F}$ groups) were kept at $12-18{ }^{\circ} \mathrm{C}$ and $70-75 \%$ relative moisture.

The eggs in groups with chitosan cover (A, C and $\mathrm{E}$ groups) were kept at $18-20{ }^{\circ} \mathrm{C}$ for $1-2$ hours prior to film coating, in order to avoid water condensation on their shells. Chitosan film was diluted with distilled water at $1 \%$ concentration, homogenized via magnetic vortex, and $1 \%$ acetic acid was added in order to improve the solubility and efficacy. This solution was mixed using magnetic vortex for 45 minutes at low temperature $(37 \pm 2$ $\left.{ }^{\circ} \mathrm{C}\right)$, and plasticizer $(0,25 \mathrm{ml}$ gliserol/g chitosan) was

Table 1. The experimental design of the study *.

\begin{tabular}{|c|c|c|c|}
\hline \multirow{2}{*}{$\begin{array}{c}\text { Storage } \\
\text { period (day) }\end{array}$} & \multicolumn{2}{|c|}{ Chitosan film coating } & \multirow{2}{*}{$\begin{array}{c}\text { Amount of } \\
\text { eggs }\end{array}$} \\
\hline & Situation & Groups & \\
\hline \multirow[b]{2}{*}{7} & 1 & A & 300 \\
\hline & 2 & B & 300 \\
\hline \multirow{2}{*}{14} & 1 & $\mathrm{C}$ & 300 \\
\hline & 2 & $\mathrm{D}$ & 300 \\
\hline \multirow{3}{*}{21} & 1 & E & 300 \\
\hline & 2 & $\mathrm{~F}$ & 300 \\
\hline & & Total & 1800 \\
\hline
\end{tabular}

*: Study was independently repeated 3 times, 1 (A, C, E): chitosan film coated, 2 (B, D, F): no chitosan film coated.

added to the solution in order to avoid fragility of the coating and to strengthen the film layer. The solution was mixed using a magnetic vortex for 15 minutes at low temperature $\left(37 \pm 2{ }^{\circ} \mathrm{C}\right.$ ) (Bhale et al., 2003; Caner and Cansiz 2007). The eggs were covered by immerging into the freshly prepared solution for 1 minute, waiting for room temperature $\left(20-21{ }^{\circ} \mathrm{C}\right)$ for 15 minutes, and immerging into the solution for 1 minute again (Xie et al., 2002). The eggs covered with chitosan were kept at proper room conditions $\left(20-21{ }^{\circ} \mathrm{C}\right.$ and $50-55 \%$ humidity) for drying and stored at the same storage conditions $\left(15 \pm 0,5^{\circ} \mathrm{C}\right)$ with the control groups until transferring into the setter part of the incubator.

At the same time, placing all the eggs in the same incubator and follow-up; the eggs were brought from hatching company on day zero, and stored according to a schedule. The eggs stored for 7 days were transferred to the hatching incubator primarily, and a week later, 14 day-eggs were transferred, and 2 weeks later, the 21 day stored eggs were transferred. All eggs were weighed for a second time prior to transfer into the incubator. In this study, eggs were incubated in an incubator (ÇIMUKA ${ }^{\mathrm{TM}}$, TURKEY) with capacity of 2400 chicken eggs with automatic regulation of temperature and relative humidity. Eggs were automatically turned in interval of four hours.

On the $6^{\text {th }}, 8^{\text {th }}$ and $18^{\text {th }}$ day of incubation in the hatching incubator $\left(37.8{ }^{\circ} \mathrm{C}, \quad 55-60 \%\right.$ moisture $)$, fertilization control was carried out with light, and those that were not fertilized, were removed from the incubator. The dead embryos were categorized as early ( $<7$ days), mid-term (7-14 days) and late $\left(15-18^{\text {th }}\right.$ days + no hatching) embryo deaths, and the rates were calculated according to the following formulas; 


$$
\begin{aligned}
& \text { Ecrly embryonic mortaity }(\%)=\frac{\text { number of embryos that had died in theeary }- \text { term }}{\text { number of fersilized } 6 g g s} \times 100 \\
& \text { Mid - term embryonic mortality }(\%)=\frac{\text { mumber of enbryos that had diad in the mid }- \text { term }}{\text { number of fertilizad eggs }} x 100 \\
& \text { Late embryo nic mortahty }(\%)=\frac{\text { number of embryos that had died in the late }- \text { term }}{\text { nember of fertilized eggs }} \times 100
\end{aligned}
$$

Transfer of the eggs to hatching incubator and follow-up: hatching was controlled from the $21^{\text {st }}$ day to the end of $22^{\text {nd }}$ day, and those that had not hatched were removed and examined. In this study, the fertilization rate, hatching efficiency, and the hatchability were calculated for each group according to the following formula:

$$
\begin{aligned}
& \text { Fertility }(\%)=\frac{\text { number of fertutized eggs }}{\text { total number of eggs placed into the incubator }} x 100 \\
& \text { Hatchability }(\%)=\frac{\text { number of hatched chicks }}{\text { total number of eggs placed into the incubator }} \times 100
\end{aligned}
$$

The egg weight loss rate was calculated using the following formula;

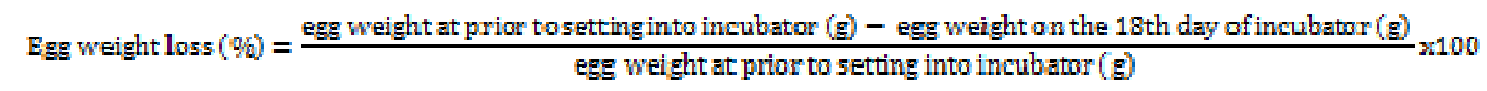

Statistical analyses. In this study, data were analyzed by two-way ANOVA using the General Linear Model (GLM) procedure (SPSS, 2015). The 3 (storage period) $\mathrm{x}$ 2 (coating the chitosan film of the the eggs or not) factorial research design was used to investigate the effects of the factors (storage period and coating the chitosan film) on pre-storage and post-storage weights $(\mathrm{g}), 18^{\text {th }}$ day weight $(\mathrm{g})$ in incubation and egg weight losses (\%).The effects of the factors (storage period and coating the chitosan film) and the interactions between the factors were analyzed assuming the following model: $\mathrm{Y}_{\mathrm{ijk}}=\mu+\mathrm{a}_{\mathrm{i}}+\mathrm{b}_{\mathrm{j}}+(\mathrm{ab})_{\mathrm{ij}}+\mathrm{e}_{\mathrm{ijk}}$

Where $Y_{\mathrm{ijk}}=$ observed value of the investigated parameter, $\mu=$ population mean; $a_{i}=$ effect of storage period $(\mathrm{i}=1,2$ and 3$), \mathrm{b}_{\mathrm{j}}=$ chitosan film coating $(\mathrm{j}=1$ :chitosan film coating, 2 : none with chitosan coating film), $(a b)_{i j}=$ effects of interaction between storage period and chitosan film coating, $e_{\mathrm{ijk}}=$ random error associated with $\mathrm{k}^{\text {th }}$ observation on $\mathrm{j}^{\text {th }}$ coating during $\mathrm{i}^{\text {th }}$ storage period NID, $\left(\mathrm{O}, \sigma^{2}\right)$.

The differences among the treatment groups were evaluated by Duncan Multiple Range Test (DMRT). Also, statistical significance was considered at $\mathrm{P}<0.05$ (SPSS, 2015). The Chi-square test was used to analyze the fertility, hatchability and embryonic mortality rates (Snedecor and Cochran 1980; Ozdamar, 2003; Akgul, 2005).

\section{RESULTS AND DISCUSSION}

The effects of chitosan film coating and different periods storing on egg weights before storage, egg weights at the beginning of incubation, egg weights at $18^{\text {th }}$ day of incubation and egg weight losses were presented in Table 2.

According to this study, the differences between the eggs weights before loading in the incubator and the eggs weights before storage were found to be statistically significant $(p<0.05)$. Also, it was calculated that the average eggs weight before storage were $59.9 \pm 0.1 \mathrm{~g}$, the end of storage (before loading the eggs into the incubator) were $58.6 \pm 0.1 \mathrm{~g}$. The mean weight of the eggs was $54.0 \pm 0.1 \mathrm{~g}$ on the $18^{\text {th }}$ day of incubation. The lowest weight loss was observed in the group A with a mean of $6.8 \pm 0.1 \mathrm{~g}$, although the highest weight loss was observed in the group D with a mean of $9.7 \pm 0.3 \mathrm{~g}$. The eggs weights were examined considering the duration of storage, and it was observed that the degree of weight loss increased due to prolongation of storage.

The effect of the storage period on the egg weights at the $1^{\text {st }}$ and $18^{\text {th }}$ day of incubation was significant $(p<0.05)$, but it's effect on egg weight loss was not significant $(p>0.05)$. The eggs weight on the 18 th day of incubation were also found to have significant effects between different treatment groups $(\mathrm{p}<0.05)$.

On the other hands, the differences in egg weight loss between the groups with chitosan films and the groups without chitosan film were significant and also the effect of chitosan film coating on the eggs weights at the the $1^{\text {st }}$ and $18^{\text {th }}$ day of incubation and eggs weight loss was significant $(p<0.05)$. A significant difference was observed between the treatment groups with and without chitosan film coating with regard to weight loss on the $18^{\text {th }}$ day of incubation. It was demonstrated that chitosan 
film reduced the weight and water losses of the eggs, therefore, weight loss increased due to prolongation of storage time.

In addition, the comparisons between groups with and without chitosan film coating at each different duration of storage ( 7,14 and 21 days) revealed a not significant reduction in weight losses $(\mathrm{p}>0.05)$ (Table 2$)$. However, the differences between storage time groups in chitosan film coated and uncoated groups were not significant for egg weight loses $(\mathrm{p}>0.05)$.

In the present study, the interaction effect between the storage period and the chitosan film coating on all the traits (except for the eggs weights of before storage) was significant ( $\mathrm{p}<0.05)$.

The pores on the surface of the egg shells are plugged with chitosan film to a certain extent, and water vaporization and air transfer through the shell is prevented, which in turn results in minimalized weight loss from the eggs, because gas permeability through edible film covers of polysaccharide structure is low, and due to their hydrophillic structure, the physical moisture barrier property is low as well (Baldwin 1994; Gontard et al., 1996). In these cases the egg weight losses, related to progressive deterioration of the internal quality of the egg, is responsible for the decreased in hatchability (González-Redondo et al., 2010). However, maintaining the inner moisture via such a film also demonstrates the presence of a good barrier against water vapor pressure (Baldwin 1994).

In this study, fertility, early-mid- and late-term embryonic mortality, and hatchability have been presented in Table 3.

Table 2. Effects of chitosan film coating and different periods storing on eggs weight (g) and eggs weight losses (\%), (Mean \pm Standard Error Mean, SEM).

\begin{tabular}{|c|c|c|c|c|c|}
\hline \multicolumn{2}{|c|}{ Storage period (day) } & $\begin{array}{c}\text { Egg weights before } \\
\text { storage }\end{array}$ & $\begin{array}{c}\text { Egg weights before } \\
\text { incubation }\end{array}$ & $\begin{array}{c}\text { Egg weights } \\
18^{\text {th }} \text { day }\end{array}$ & $\begin{array}{c}\text { Eggs weight } \\
\text { losses }\end{array}$ \\
\hline \multicolumn{2}{|c|}{7} & $60.2 \pm 0.2$ & $59.3 \pm 0.2^{\mathrm{y}}$ & $55.3 \pm 0.2^{y}$ & $8.2 \pm 0.1$ \\
\hline \multicolumn{2}{|c|}{14} & $59.9 \pm 0.2$ & $58.7 \pm 0.2^{x}$ & $53.7 \pm 0.2^{x}$ & $8.5 \pm 0.2$ \\
\hline \multicolumn{2}{|c|}{21} & $59.7 \pm 0.2$ & $58.1 \pm 0.2^{x}$ & $53.2 \pm 0.2^{x}$ & $8.4 \pm 0.1$ \\
\hline \multicolumn{2}{|c|}{ Chitosan film coating } & \multirow{2}{*}{$\begin{array}{c}\text { Egg weights before } \\
\text { storage }\end{array}$} & \multirow{2}{*}{$\begin{array}{c}\text { Egg weights before } \\
\text { incubation }\end{array}$} & \multirow{2}{*}{$\begin{array}{c}\text { Egg weights } \\
18^{\text {th }} \text { day }\end{array}$} & \multirow{2}{*}{$\begin{array}{l}\text { Egg weights } \\
\text { losses }\end{array}$} \\
\hline Situation & Groups & & & & \\
\hline 1 & $\mathrm{~A}$ & $60.2 \pm 0.2$ & $59.2 \pm 0.2^{\mathrm{cd}}$ & $56.0 \pm 0.2^{\mathrm{c}}$ & $6.8 \pm 0.1^{\mathrm{a}}$ \\
\hline 2 & $\mathrm{~B}$ & $60.2 \pm 0.2$ & $59.4 \pm 0.2^{\mathrm{d}}$ & $54.5 \pm 0.2^{b}$ & $9.5 \pm 0.1^{b}$ \\
\hline 1 & $\mathrm{C}$ & $59.9 \pm 0.2$ & $58.9 \pm 0.2^{\mathrm{bcd}}$ & $54.6 \pm 0.2^{b}$ & $7.2 \pm 0.1^{\mathrm{a}}$ \\
\hline 2 & $\mathrm{D}$ & $59.8 \pm 0.2$ & $58.5 \pm 0.2^{\mathrm{abc}}$ & $52.8 \pm 0.2^{\mathrm{a}}$ & $9.7 \pm 0.3^{b}$ \\
\hline 1 & $\mathrm{E}$ & $59.7 \pm 0.2$ & $58.3 \pm 0.2^{\mathrm{ab}}$ & $54.0 \pm 0.2^{\mathrm{b}}$ & $7.2 \pm 0.1^{\mathrm{a}}$ \\
\hline \multirow[t]{2}{*}{2} & $\mathrm{~F}$ & $59.7 \pm 0.2$ & $57.9 \pm 0.1^{\mathrm{a}}$ & $52.3 \pm 0.2^{\mathrm{a}}$ & $9.6 \pm 0.1^{b}$ \\
\hline & Total & $59.9 \pm 0.1^{\phi}$ & $58.6 \pm 0.1^{¥}$ & $54.0 \pm 0.1$ & $8.3 \pm 0.1$ \\
\hline Storage period & & - & * & ${ }^{*}$ & - \\
\hline Chitosan film & & - & $*$ & $*$ & * \\
\hline Storage period $x$ & $\mathrm{n}$ film coating & - & * & $*$ & $*$ \\
\hline
\end{tabular}

The effect of storage periods on early, mid-late embryo mortality and hatchability were not significant $(\mathrm{P}>0.05)$. The effect of chitosan film coating on early, mid-late embryonic mortality and hatchability was significant $(p<0.05)$. No significant difference was determined between the groups with regard to fertility rates in the study $(p>0.05)$ and very high early-term embryonic mortality was observed in all of the chitosan film coating groups. Also, the interaction effects between the storage period and the chitosan film coating factors were not significant for early, mid-late embryonic mortality and hatchability $(\mathrm{P}>0.05)$ (Table 3 ).

In groups with no chitosan film, the early-term embryonic mortality varied between $8.27 \%-17.24 \%$ was calculated. The embryonic mortality increased because of storage time. This was the case in mid- and late-term embryos as well. A shorter storage provides better protected inner quality, better development of the embryo and reduced weight loss.

The results of this study were similar to the results of some researchers who reported that storing eggs for more than 7 days adversely affected embryo development and embryonic mortality (Fasenko et al., 1992; Saylam 1999; Altan et al., 2002). In additonally, it has been reported that high embryonic mortality resulting from long-term storage of eggs may be associated with adverse changes in egg albumin or $\mathrm{pH}$ (Meijerhof 1994).

In groups with chitosan film, almost all embryos had died in the early-term, thus, very few embryos reached mid- or long-term. Therefore, the mid- or long- 
term embryonic mortality appeared $2.41-6.89 \%$ so low. It is obviously understood that chitosan film completely covers the surface of the egg, plugs the pores on the shell, forms a barrier between the inner and outer environment of the egg, and thus, the weight loss of the egg is reduced. The main purpose of these cover materials is to keep the shell dry, and reduce oxygen input and carbondioxide and moisture output of the egg (Tayyar 2005). Such film materials provide positive effects on the inner and outer quality parameters of the eggs for commercial use (Bhale et al., 2003); however, for hatching, it has significant negative effects on the embryo development due to the need of oxygen intake and exhausting of carbondioxide and water vapor formed within the egg, and leads to death of the embryo (Dorosti et al., 2019). Therefore, it is considered that almost no embryo hatching can be observed in all the groups with chitosan film coating.

In the study, hatchability varied between $78.33 \%$ and $85.33 \%$ in without chitosan film coating groups. The hatchability in the groups having eggs coating with chitosan film changed between $40.69 \%$ and $44.48 \%$ (Table 3). In all the groups, the hatchability was decreased with the increase in the duration of storage Similarly, some studies have reported that the hatchability of incubated eggs decrease when the eggs are stored for longer than a week (Ipek et al., 1999; Altan et al., 2002). However, in this study, contrary to expectations, this decrease was not statistically significant.

Table 3. Effects of chitosan film coating and different periods storing on hatchability characteristics (\%)

\begin{tabular}{|c|c|c|c|c|c|}
\hline \multicolumn{2}{|c|}{ Storage period (day) } & Fertility & $\begin{array}{c}\text { Early embryonic } \\
\text { mortality }\end{array}$ & $\begin{array}{c}\text { Mid-late embryonic } \\
\text { mortality }\end{array}$ & Hatchability \\
\hline \multicolumn{2}{|c|}{7} & 96.67 & 52.59 & 2.93 & 44.48 \\
\hline \multicolumn{2}{|c|}{14} & 96.50 & 52.16 & 3.45 & 44.39 \\
\hline \multicolumn{2}{|c|}{21} & 96.67 & 55.00 & 4.31 & 40.69 \\
\hline \multicolumn{2}{|c|}{ Chitosan film coating } & \multirow{2}{*}{ Fertility } & \multirow{2}{*}{$\begin{array}{c}\text { Early embryonic } \\
\text { mortality }\end{array}$} & \multirow{2}{*}{$\begin{array}{c}\text { Mid-late embryonic } \\
\text { mortality }\end{array}$} & \multirow{2}{*}{ Hatchability } \\
\hline Situation & Groups & & & & \\
\hline 1 & $\mathrm{~A}$ & 96.67 & $96.89^{c}$ & $2.41^{\mathrm{ab}}$ & $0.67^{\mathrm{a}}$ \\
\hline 2 & $\mathrm{~B}$ & 96.67 & $8.27^{\mathrm{a}}$ & $3.44^{\mathrm{ab}}$ & $85.33^{b}$ \\
\hline 1 & $\mathrm{C}$ & 96.33 & $92.73^{\mathrm{c}}$ & $4.15^{\mathrm{ab}}$ & $3.00^{\mathrm{a}}$ \\
\hline 2 & $\mathrm{D}$ & 96.67 & $11.72^{\mathrm{a}}$ & $2.75^{\mathrm{ab}}$ & $82.66^{\mathrm{b}}$ \\
\hline 1 & $\mathrm{E}$ & 96.67 & $92.75^{\mathrm{c}}$ & $6.89^{b}$ & $0.33^{\mathrm{a}}$ \\
\hline \multirow[t]{2}{*}{2} & $\mathrm{~F}$ & 96.67 & $17.24^{\mathrm{ab}}$ & $1.72^{\mathrm{a}}$ & $78.33^{b}$ \\
\hline & Total & 96.61 & 53.25 & 3.56 & 41.72 \\
\hline Storage period & & - & - & - & - \\
\hline Chitosan film & & - & $*$ & $*$ & $*$ \\
\hline Storage period $x$ & n film coating & - & - & - & - \\
\hline
\end{tabular}

Conclusions: In conclusion that, coating with chitosan film which is obtained from natural chitin that has no harmful effect on the environment, animals or human, and storing for different storage times of brood broiler eggs, was observed to significantly reduce weight losses of the eggs during both storage and incubation. Conversely, the coating of eggs with chitosan film adversely affected the embryonic mortality and the hatching performance.

Acknowledgments: We thank the financial support of the Unit of the Scientific Research Projects of Inonu University, TURKEY (Grant No: FCD-2017-703).

Conflict of interest: The authors declare no conflict of interest.

\section{REFERENCES}

Akgul A. (2005). Tıbbi Araştırmalarda İstatistiksel Analiz Teknikleri. 3. Ed., Emek Ofset Ltd Şti., Ankara, Turkey.

Aksoy T. (1991). Tavuk Yetiştiriciliği. Ankara Şahin Press, Ankara, Turkey.

Altan O., A. Altan, H. Bayraktar, and A. Demircioglu (2002): Effect of short-term storage on hatchability and total incubation period of breeder hatching eggs. Tr. J.Vet. Anim. Sci. 26: 447-452.

Avan T., and M. Alisarli (2002). The effect of storage conditions on the physcial, chemicial and microbiological quality of the egg. Van Vet J. 13: 98-107.

Baldwin E.A. (1994). Edible coatings for fresh fruits and vegetables: past, present and future. In: Krochta J.M., Baldwin E.A., Nisperos-Carriedo M.O. (ed): Edible Coatings and Films to Improve 
Food Quality. Technomic Publishing Company Inc, Lancaster, UK, 25-64.

Berardinelli A., V. Donati, A. Giunchi, A. Guarnieri, and L. Ragni (2003). Effects of sinusoidal vibrations on quality indices of shell eggs. Biosystems Engineering. 86: 347-353.

Bhale S., H.K. No, W. Prinyawiwatkul, A.J. Farr, K. Nadarajah, and S.P. Meyers (2003). Chitosan coating improves shelf life of eggs. J Food Sci. 68: 2378-2383.

Brake, T.J., J. Walsh, C.E. Benton, J.N. Petitte, R. Meijerhof, and G. Penalva (1997). Egg handling and storage. Poult. Sci. 76: 144-151.

Caner C. (2005). The effect of edible eggshell coating on egg quality concumer perception. J. Sci. Food Agric. 85: 1897-1902.

Caner C., and O. Cansiz (2007). Effectiveness of chitosan-based coating on improving shelf life of eggs. J. Sci. Food Agric. 87: 227-232.

Dorosti, M.A., A. Shaddel Teli, and M. Salmanzadeh (2019). Effects of coating breeding eggs with different materials on quality of stored eggs and hatching results. J. Livestock Sci. 10: 1-5.

Durmus I., S. Kamanli, and H. Aygoren (2009). Effects of coating breeding eggs with different materials on hatching results. JPR, 8: 23-25.

Fasenko G.M., F.E. Robinson, R.T. Hardin, and J.L. Wilson (1992). Variability in preincubation embriyonic development in domestic fowl. 2 . Effects of duration of egg storage period. Poult. Sci. 71: 2129-2132.

Gontard N., R. Thibault, B. Cuq, and S. Guilbert (1996). Influence of releative humidity and film composotion on oxygen and carbondioxide permaabilities of edible films. J. Agric. Food Chem. 44: 1064-1069.

González-Redondo P., M. Delgado-Pertiñez, S. Toribio, F.A. Ruiz, Y. Mena, F.P. Caravaca, and J.M. Castel (2010). Characterisation and typification of the red-legged partridge (Alectoris rufa) game farms in Spain. Span. J. Agric. Res.8: 624-633.

Ipek A., U. Sahan, and Z. Yildirim (1999). Effects of storage time and positions on incubation properties of meat main stud eggs. The J. Agricultural Faculty of Uludag University.

Kucukoner E., O. Kilincceker, and S. Dogan (2003). Gıdalara yenilebilir kaplama uygulamalarında süt ürünlerinin kullanım olanakları. In: Süt Endüstrisinde Yeni Eğitimler Sempozyumu (SEYES), İzmir, Turkey. 251-256.

Lee J.Y., H.J. Park, C.Y. Lee, and W.Y. Choi (2003). Extending shelf-life of minimally processed apples with edible coatings and antibrowning agents. LWT - Food Sci. Technol. 36: 323-329.

Mcwilliams M. (2001). Eggs. Foods, Experimental
Perspectives. 16: 355- 377.

Meijerhof R. (1992): Pre-incubation holding of hatching eggs. World Poultry Sci. J. 48: 57-68.

Meijerhof R. (1994). Theoretical and empirical studies on temperature and moisture loss of hatching eggs during the pre-incubation period. Ph.D. Dissertation. University of Wageningen, Netherlands.

No K.H., W. Prinyawiwatkul, and S.P. Meyers (2005). Comparisonof shelf life of eggs coated with chitosans prepared under various deproteinization and demineralization times. J Food Sci. 70: 377-382.

Otles S., and Y. Hisil (1990). Tavuk yumurtasının (Gallus Domesticus) kalite birimleri üzerine depolama süresinin ve kaplama metodlarının etkisi. JPR. 3: 18-23.

Ozdamar K. (2003). SPSS ile Biyoistatistik. 5. Ed., Kaan Press. Ankara.

Reijrink I.A.M., R. Meijerhof, B. Kemp, and H. Van den Brand (2008). The chicken embryo and its micro environment during egg storage and early incubation. World Poultry Sci. J. 64: 581- 598.

Saylam S.K. (1999). The effects of egg weight and storage time on egg weight loss and hatchability traits in japanese quail. Tr. J. of Veterinary and Animal Sci. 23: 367-372.

Senkoylu N. (2001). Yumurtanın Biyolojik Özellikleri. Modern Tavuk Üretimi, 3. Ed., Anadolu Press, Tekirdağ, Turkey. 55-64.

Snedecor G.W., and W.G. Cochran (1980). Statistical Method. 7. Ed., The Iowa State University Press, Ames, Iowa, U.S.A.

SPSS. (2015). Statistical Package in Social Sciences for Windows, 22.0. Chicago, USA.

Suyatma N.E., L. Tighzert, and A. Copinet (2005). Effects of hydrophilic plasticizers on mechanical, termal, and surface properties of chitosan films. J. Agric. Food Chem. 53: 39503957.

Tayyar, M. (2005). Yumurta Hijyeni. http://homepage.uludag.edu.tr/ mtayyar/yumurta hijyeni.htm (accessed 30 October, 2018).

Walsh T.J., R.E. Rizk, and J. Brake (1995). Effects of tempareture and carbon dioxide on albumen characteristics, weight loss and early embryonic mortality of long stored hatching eggs. Poult. Sci. 74: 1403-1410.

Xie L., N.S. Hettiarachchy, Z.Y. Ju, J. Meullenet, H. Wang, M.F. Slavik, and M.E. Janes (2002). Edible film coating minimize eggshell breakage and reduce post-wash bacterial contamination measured by dye penetration in eggs. J Food Sci. 67: $280-284$. 